\title{
Continent Orthotopic Diversion
}

National Cancer Institute

\section{Source}

National Cancer Institute. Continent Orthotopic Diversion. NCI Thesaurus. Code C127177.

Continent urinary diversion procedure in which the ureters are connected to a surgicallycreated neo-bladder that is also connected to the urethra so that the patient can empty the bladder normally. 